\title{
Mother-Infant Interaction in Lymphocytic Choriomeningitis Virus Infection of the Newborn Mouse: The Effect of Maternal Health on Mortality of Offspring
}

\author{
John Hotahin ${ }^{[22]}$, Lois Benson and Jane Gardner \\ Division of Laboratories and Research, New York, \\ State Department of Health, Albany, New York, USA
}

\begin{abstract}
Extract
The health of mothers was found to influence mortality of infant mice inoculated at 2 days of age with lymphocytic choriomeningitis (LCM) virus. When a normal mother (not exposed to LCM) was exchanged on day 9 after infection of the offspring with the original mother of LCM-inoculated mice a $20 \%$ decrease in mortality was observed, and when two mothers per litter were used the mortality dropped by $32 \%$. Substitution of the original mother of uninoculated 9-day-old infant mice with a mother from LCM-infected mice induced a $15 \%$ greater mortality above the control level.

Daily exchange (rotation) of mothers increased mortality of LCM-inoculated mice to $100 \%$ from the usual value of $71 \%$, but only induced $11 \%$ mortality in uninoculated controls. Weight, and immunity tests, of mothers of infected mice showed that they received contact infection that caused mild illness, but resulted in increased infant mortality (IM).
\end{abstract}

\section{Speculation}

Lymphocytic choriomeningitis virus used as an infectious agent in mice indicate that sick infant mice are very susceptible to minor changes in maternal care, consequent upon mild or subclinical infection. Illness of both mother and offspring apparently results in a synergistic lethal effect resulting in exaggerated IM. Although it appears likely that IM arises from poor maternal care, other factors such as milk composition, including antibody content, may be involved, and may be relevant to comparable situations in man.

\section{Introduction}

It is well known that social factors, particularly those producing stress, can significantly affect infant animals, especially during critical developmental periods [13]. Similar interactions can apparently occur via the transmission of infectious agents with a consequent modification of the social process by disease. The maternal role may be altered sufficiently to cause fatal results in a proportion of infants. In the course of experiments involving the inoculation of newborn mice with LCM virus [5], variable results were obtained that appeared to be due to differences in the health 
and possibly the behavior of the mothers. The impression was gained in this laboratory and elsewhere [15] that IM [17] might depend to some extent on the acquisition of LCM infection by mothers that had suckled LCM-inoculated infants. Solid immunity subsequently develops in these mothers $[1,8]$.

Previous investigations [6] showed that mice inoculated intracerebrally with LGM during the first few hours after birth exhibited no signs of illness although the same virus, inoculated by the same route, caused severe disease in adult mice. An inverse relation was found to exist between age at inoculation and the number of surviving mice. This was correlated with the severity of the cellular immune response of the animal to the virus. All mice that survived were found to exhibit persistent tolerant infection [6,9]. With suitable 'docile' strains of LCM virus, IM of newborn mice was as low as $20 \%$. whereas with virulent or 'aggressive' strains, IM was $100 \%[5,10]$.

A series of experiments was performed using LCM virus infection of mice neonatally in which the mothers were exchanged or 'rotated' at various intervals. The effect of the mother substitutions on IM was studied and attempts were made to correlate the results with the state of health and LCM immunity of the mother.

\section{Materials and Methods}

Virus

The virus used was the LCM-UBC strain originally derived from the WE strain from the Rockefeller Institute. Two preparations were used.

A viscerotropic 'docile' strain, associated with good tolerance-inducing ability and low mortality in infant mice [9], was used to inoculate newborn mice, 2 to 3 days old. The virus had been passed in adult mice 6 times as mouse brain suspension (intracerebral inoculation) and then 11 times as a mouse liver suspension (intraperitoneal inoculation) $\left(\mathrm{M} / \mathrm{B}_{6} \mathrm{~L}_{11}\right)$. A $20 \%$ suspension of pooled mouse livers comprised the final virus pool in serum broth salt diluent (beef infusion broth $45 \%$, inactivated horse serum $5 \%$, in $0.85 \%$ sodium chloride solution) stored in vials at $-80^{\circ}$. For inoculation the pooled suspension was diluted in $0.05 \%$ gelatin in tris (hydroxymethyl) amino methane-1,3-propanediol (Tris)-buffered Hanks' saline (GTH), pH 7.2, with the addition of 100 units penicillin and $100 \mu \mathrm{g}$ streptomycin $/ \mathrm{ml}$. Each mouse inoculum $(0.02 \mathrm{ml})$ contained $6 \times 10^{3} \mathrm{LD}_{50}$.

A neurotropic, aggressive strain [9] used for challenge caused high mortality in infant mice and a low tendency to induce tolerance. This strain had received seven passes by the intracerebral route $\left(M / B_{7}\right)$ using mouse brain as inoculum; a final pool was prepared consisting of a $20 \%$ suspension of mouse brains in broth salt solution, with $10 \%$ skim milk, 100 units penicillin, and $100 \mu \mathrm{g}$ streptomycin $/ \mathrm{ml}$. Each mouse inoculum $(0.03 \mathrm{ml})$ contained $6 \times 10^{3} \mathrm{LD}_{50}$.

\section{Mice}

Albino mice of the Albany strain were used from a colony developed in this laboratory 25 years ago. The mice were randomized into litters with one mother and eight babies caged separately, 20 litters/experiment [19].

\section{Calculations}

The percentage mortality was calculated for each experimental condition using the formula:

$$
\frac{N_{5}-S_{d}}{N_{5}} \times 100
$$

where $\mathrm{N}_{5}$ is the number of infants alive on day $5 ; \mathrm{S}_{\mathrm{d}}$ is the number of infant survivors on a given day. This eliminated from the data a few cases where mothers failed to care for their young. Such numbers were insufficient to affect the conclusions but were eliminated since they reduced the 'background' of nonspecific deaths. In our experience, only a small proportion of lactating females exhibited cannibalism or complete neglect of the infants, which was evidenced by the failure of the dam to nurse or make a nest for the infants, and resulted in death of the whole litter prior to day 5. Analysis of the results showed that although such deaths raised the 'background noise-level' the conclusions were not affected.

Calculatior of average day of death of infants. This average was the sum of days of death of infants divided by the number of dead infants. Any deaths before day 5 were discounted, as previously stated.

Average day of onset of symptoms in the mother. The average day of onset of symptoms in the dam was calculated in the same manner as average day of death of infants.

Weights of mothers. Weights [18] of mothers were recorded from day 1 to 28 after infant inoculation. The total daily weights for each experiment were averaged to give the average weight of mothers.

\section{Experimental Conditions}

Eight experiments, each involving approximately 20 litters of mice, were performed to determine whether the exchange of mothers during infant infection had a deleterious effect on the offspring. There were three major experimental groups; they consisted of infected newborn mice that would 1) have no exchange of mothers; 2) have a single maternal exchange on day 9 or 10 ; and 3 ) have a multiple maternal exchange (daily). 


\section{Results}

Studies of Infant Mortality

No exchange of mothers. Under this experimental condition, infant mice that had been inoculated with LCM virus remained with their uninoculated mothers throughout. Two experiments with 19 and 16 litters [19] of mice were conducted and the IM was 69 and $73 \%$, respectively (table I, fig. 1 ), well within the previously demonstrated [10] range of 62-82\% mortalities with LCM-inoculated infants; average day of death was 12.0 and 12.1 , respectively. Thus, in the absence of mother exchanging, the infant mortality was approximately $71 \%$.

Single maternal exchange. Mothers of LCM-inoculated infant mice (table II, fig.2) were exchanged on day 9 for mothers of uninoculated infant mice since day 9 was just before the onset of maternal illness. The LCMinoculated infants, which had been given healthy mothers (from normal infants) on day 9, showed a lower cumulative mortality, $51 \%$ (table II), measured on day 28 postinoculation and a slightly later mean day of death at 13.7 than those in the nonexchange experiments. The difference in IM between the nonexchange (table I) and single exchange (table II) LGM-inoculated mice was highly significant ( $P$ $<0.001$; chi-square method). Likewise, the difference in IM between LCM- and uninoculated infant mice, where there had been a single maternal interchange (table II), was highly significant $(P<0.001)$. These results appeared to indicate that some of the expected IM was due to maternal morbidity. The uninoculated infant mice, which had acquired sick mothers (from LGM-infected mice) on day 9 , had $17 \%$ mortality; $2 \%$ of the deaths occurred before the new mothers were introduced and 15\% occurred within 10 days after exposure to the sick mothers.

Two control groups consisting of 20 litters each of normal, uninoculated infants and mothers were also included; mothers of these two groups were exchanged on day 9. The infants showed 0 and $7.1 \%$ mortality measured on day 25 (table II, fig. 2). In the latter uninoculated group, $5.7 \%$ of the total IM $(7.1 \%)$ was due to the death of one entire litter probably owing

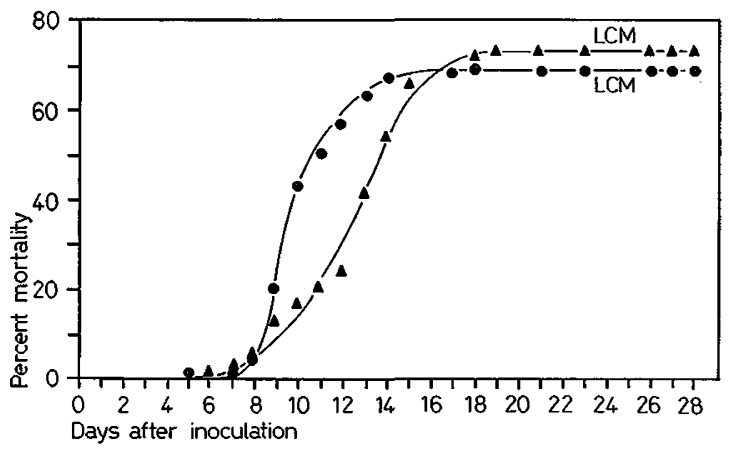

Fig. 1. Cumulative mortality curves of infant mice that received a neonatal inoculation of LGM virus. The two curves represent two different experiments, and $\boldsymbol{\Lambda} \longrightarrow \mathbf{\Delta}$.

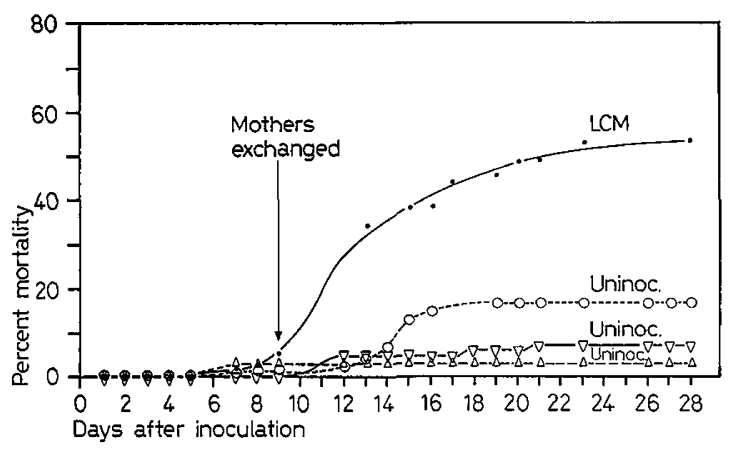

Fig. 2. Cumulative mortality curves of infant mice with and without LGM virus. Mothers were exchanged on day 9 between $\bullet-$ and $\bigcirc----\circ:$ LCM and uninoculated; on day 10 between $\Delta \longrightarrow \Delta$ and $\nabla---\nabla:$ uninoculated and uninoculated.

Table I. Maternal and infant mortality following neonatal inoculation of mice with LCM virus (no maternal exchanges)

\begin{tabular}{|c|c|c|c|c|c|}
\hline \multicolumn{3}{|c|}{ Infant mice } & \multicolumn{3}{|c|}{ Mother mice } \\
\hline Mortality ratio ${ }^{1}$ & $\begin{array}{c}\text { Mortality, } \\
\%\end{array}$ & $\begin{array}{c}\text { Mean day of } \\
\text { death }\end{array}$ & $\begin{array}{l}\text { Mothers with } \\
\text { symptoms, \% }\end{array}$ & $\begin{array}{c}\text { Mean day of } \\
\text { symptoms }\end{array}$ & $\begin{array}{c}\text { Mothers } \\
\text { immune to } \\
\text { challenge, \% }\end{array}$ \\
\hline $100 / 145$ & 69 & 12.0 & 25 & $n t^{2}$ & 90 \\
\hline $90 / 123$ & 73 & 12.1 & 88 & 14.4 & nt \\
\hline
\end{tabular}

1 Number of mice died/number of mice total.

${ }^{2}$ Not tested until day 19. 
to parental neglect. The difference between the combined percentage IM of these two single maternal exchange uninoculated groups (well mothers) and the uninoculated single maternal exchange group (sick mothers on day 9$)$ was also very significant $(P<0.001$; chi-square method).

From these results, it appeared clear that maternal morbidity had increased IM by $20 \%$ after the 9 th day following LGM virus inoculation of infant mice. Furthermore, when mothers of these infected infants were transferred to uninoculated infant mice on day 9 , IM for these normal mice was increased by $12 \%$.

Multiple maternal exchange. A 'merry-go-round' experiment was devised involving daily maternal changes between 20 litters of LCM-inoculated infants; the mothers were moved in rotation between litters daily. By day 16 after LCM inoculation all of the infant mice had died; average day of death was 9.7 (table III, fig.3). Twenty litters of normal mothers and unin-

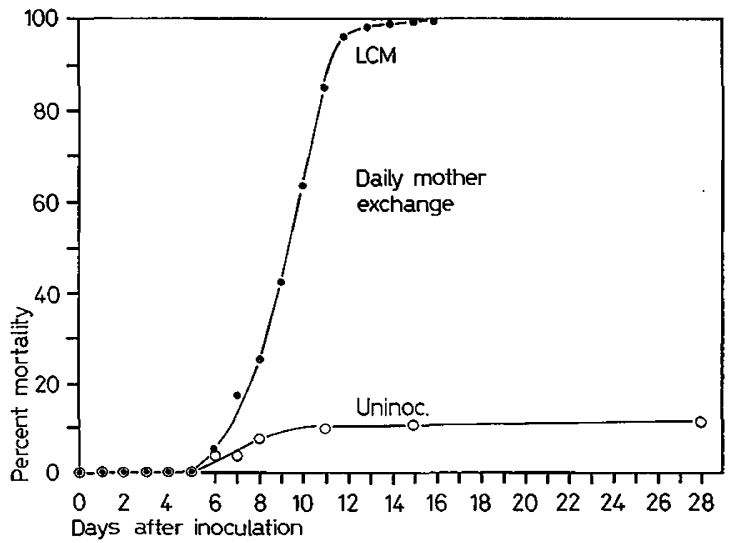

Fig.3. Cumulative mortality of infant mice whose mothers were exchanged daily within each group. $\bullet-\bullet$ : LGM. O— uninoculated.

Table II. Maternal and infant mouse mortality where mothers were exchanged between litters on day 9 relative to infant inoculation ${ }^{1}$

\begin{tabular}{lccccc}
\hline Exchange of mothers & $\begin{array}{c}\text { Infants, } \\
\text { inoculation }\end{array}$ & $\begin{array}{c}\text { Mortality } \\
\text { ratio }{ }^{2}\end{array}$ & $\begin{array}{c}\text { Infant } \\
\text { mortality, } \\
\%\end{array}$ & $\begin{array}{c}\text { Mean day } \\
\text { of death } \\
\text { of infant }\end{array}$ & $\begin{array}{c}\text { Mothers } \\
\text { immune } \\
\text { to chal- } \\
\text { lenge, } \%\end{array}$ \\
\hline Between LCM and uninoculated litters & LCM & $80 / 158$ & 51 & 13.7 & $100^{3}$ \\
Between uninoculated litters & None & $26 / 149$ & 18 & 14.5 & 92 \\
& None & $10 / 140$ & 7.1 & 12.2 & 0 \\
\hline
\end{tabular}

1 Infant mice inoculated at 2 days of age.

${ }^{2}$ Number of mice died/number of mice total.

3 Thirty percent of the mothers showed slight illness only.

Table III. Maternal and infant mortality of neonatal mice (uninoculated and LCM-inoculated) whose mothers were exchanged daily within each group of 20 litters

\begin{tabular}{lcccccc}
\hline & \multicolumn{2}{c}{ Infant mice } & & \multicolumn{2}{c}{ Mother mice } \\
\cline { 2 - 3 } Inoculation & Mortality ratio & Mortality, $\%$ & $\begin{array}{c}\text { Mean day } \\
\text { of death }\end{array}$ & $\begin{array}{c}\text { With symptoms, } \\
\%\end{array}$ & $\begin{array}{c}\text { Mean day } \\
\text { of symptoms }\end{array}$ \\
\hline LCM & $139 / 139$ & 100 & 9.7 & 95 & 14.9 \\
None & $13 / 121$ & 10.7 & 8.5 & 0 & - \\
\hline
\end{tabular}

1 Number of mice died/number of mice total. 
oculated infants undergoing similar maternal rotation showed only $10.7 \%$ IM, mean day of death being 8.5 . These experiments showed that the stress of repeated maternal exchange increased the IM of LGM-inoculated infants from the usual value of $71 \%$ up to $100 \%$. This difference was highly significant $(P<0.001$; chisquare method). Mortality prior to day 5 , as noted before, was found to be unpredictable in the uninoculated controls due to the behavior of some mothers who either failed to care for their young or were cannibalistic. Comparison of percentage IM of the uninoculated control group that had interchanged healthy mothers ( 0 and $7.1 \%$, table II) and the daily maternal exchange uninoculated infant mouse group (10.7\%, table III) showed a significant difference $(0.001<P$ $<0.01$ ).

In the infected system, IM was 10-fold greater than in an uninfected system when all families were subjected to daily mother change.

Effect of duplicate mothers upon IM. To test the conclusion that a significant component of IM was due to impaired maternal care owing to infection, an experiment was performed in which each litter was provided with two mothers in the expectation that this would decrease the IM. Ten litters of 2- to 3-day-old mice were inoculated with LCM and each litter given two mothers. A nonviral control of 10 litters with two mothers each was inoculated with normal mouse brain suspension. The mortality of the LCM infants was only $39 \%$ (table IV, fig. 4 ), about $30 \%$ less than the mortality of LCM infants with one mother (no exchange) (table I, fig. 1) and 10\% less than the mortality of infected infants receiving new, healthy mothers after day 9 (table II, fig. 2). The difference in IM between the two-mother and one-mother (no exchange) inoculated infant mice was highly significant $(P<0.001$; chisquare method), but the difference between the twomother (no exchange) and one well-mother exchangeinoculated groups was not significant $(0.10<P<0.20)$. The mean day of death in the experiments with two mothers per litter was 12.9. The uninoculated control

Table IV. Effect of giving LCM-inoculated infant mice two mothers (no mother exchange) ${ }^{1}$

\begin{tabular}{lccc}
\hline $\begin{array}{l}\text { Infant mouse } \\
\text { inoculation }\end{array}$ & $\begin{array}{c}\text { Infant mouse } \\
\text { mortality } \\
\text { ratio }^{2}\end{array}$ & $\begin{array}{c}\text { Mortality, } \\
\%\end{array}$ & $\begin{array}{c}\text { Mean day } \\
\text { of death }\end{array}$ \\
\hline LCM & $31 / 79$ & 39 & 12.9 \\
None & $0 / 72$ & 0 & - \\
\hline
\end{tabular}

1 Mothers symptoms not recorded.

${ }^{2}$ Number of mice died/number of mice total. group with two mothers showed $0 \%$ IM. These experiments confirmed the previous conclusion that a significant portion of IM due to LCM was a consequence of maternal illness.

\section{Studies of Maternal Morbidity}

Weights of mothers. Previous experiments [7] have indicated that the weight change of mice during LCM infection constitutes a reliable measure of clinical response; therefore, a comparison was made of mothermouse weight loss for the 28-day period following their exposure to LCM-inoculated infant mice. Controls were mothers of uninoculated infants. Each mother was weighed [18] daily (excepting weekends). Mortality of the LGM-inoculated infants (10 litters of eight mice each) was $63 \%$ against $5 \%$ for 10 litters of uninoculated mice.

Curves (fig. 5) of mother-mouse weight loss showed greater weight loss in the mothers of LCM-infected infants. Their weight exhibited a downward trend 6 days after virus exposure with a total drop of $6 \mathrm{~g}$ by day 19. The mothers of uninoculated mice showed a loss of only $2 \mathrm{~g}$. Subsequent challenge (with neurotropic $M / B_{7} L C M$ virus) of both groups of mothers showed that mothers of infected infants were immune.

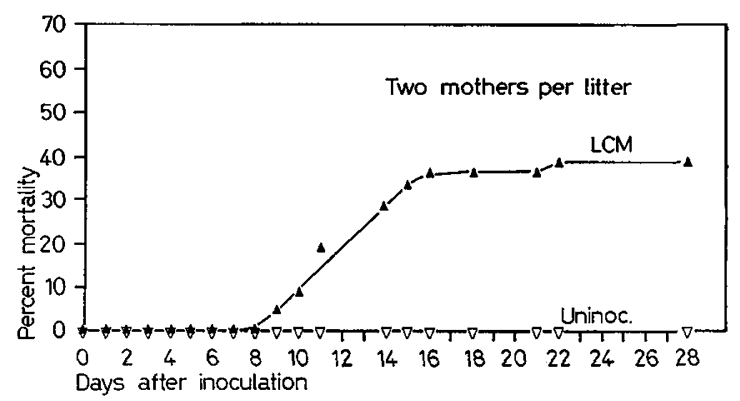

Fig.4. Cumulative mortality of infant mice given two mothers per litter. $\mathbf{A}-\boldsymbol{\Delta}$ : infants inoculated with LGM at 2 days of age. $\nabla-\nabla:$ uninoculated.

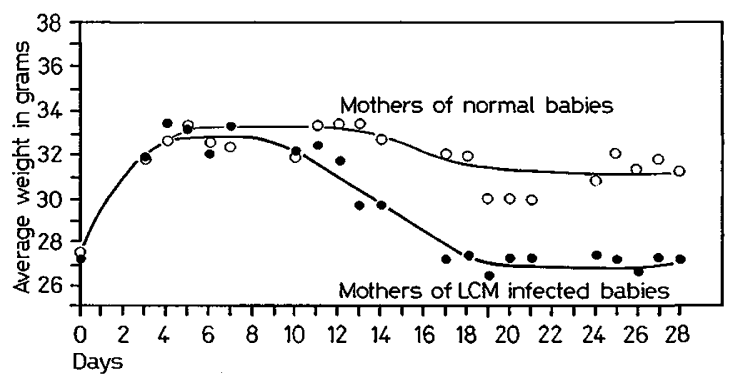

Fig.5. Average weights of dams of two groups of mice (10 litters each). - $\bullet$ received LCM-UBC M/ $\mathrm{B}_{6} \mathrm{~L}_{11}$ at 2 days of age. $\mathrm{O}-\mathrm{O}$ : uninoculated. 
Clinical illness of mothers. In addition to weight measurements, clinical response to LCM was assessed in terms of ruffled fur, blepharitis, hunched posture, and 'jumpiness'. It was found that $92 \%$ of all mothers that had nursed infants immediately after LCM inoculation showed clinical illness but none occurred in uninoculated controls. The mean day of onset of maternal illness was 14.7 days after infant inoculation, with duration of illness about 5 days. In comparing weight measurement and visible signs of illness, the former was found to be the more sensitive criterion of clinical response to LCM. The median was 14 days and coincided with the onset of visible illness.

Studies of the Immune Status of the Experimental Mice

After completion of the experiments, the mothers were challenged intracerebrally with $\mathrm{M} / \mathrm{B}_{7} \mathrm{LGM}$ virus to determine whether they were immune [16] (see final columns of tables I and II). Immunity was found in $95 \%$ of the mothers that had been with newly inoculated infant mice, and in $92 \%$ of the mothers that only came into contact with infected infants 9 days after their inoculation. This gave good agreement with the weight curves that indicated a high level of infection of mothers in all virus-exposed groups. Normal infants that received mothers from infected infants on day 9 were similarly challenged and showed $92 \%$ mortality, with illness of virtually all surviving infants, indicating that none of them had been infected by their mothers.

\section{Discussion}

These results bear out the earlier observation [9] that IM due to neonatal inoculation with LCM virus appeared to be affected by maternal illness. It seems clear that maternal morbidity is responsible in some way for a considerable portion of the IM due to LGM, and that $12-30 \%$ of this mortality can be prevented by providing a new, healthy, foster mother about day 9 , or better, providing two mothers during the whole suckling period. Conceivably, the provision of even more maternal care might help reduce IM evenfurther.

The mechanism of this maternally caused mortality is not entirely clear but unquestionably appears to be due to the rapid infection of the mothers with LCM virus after the neonatal inoculation of their offspring. This is indicated by the 6 -day interval between infant inoculation and maternal weight loss and the subsequent development of signs of illness in the mothers. Practically all mothers suffered virus infection as shown by their $95 \%$ level of challenge immunity. Further work might throw more light on the mechanism of the effect in terms of how much is due to: $a$ ) the alteration of behavior of the mother by the stress of illness. The LGM virus causes a severe generalized reaction in mice with a considerable increase in stress sensitivity as measured by endotoxin challenge [6]; b) the cessation of milk secretion; and c) the possible neurological disease of the mother, since this strain of LGM is known [2] to cause meningitis and encephalitic changes. Conceivably, behavioral changes resulting from the infection could explain the lack of care exhibited by these mothers. The fact that IM was $100 \%$ in the 'merry-go-round' experiment showed that a behavioral stress that is relatively innocuous for uninfected mice is exacerbated to lethal proportions in the virus-infected group. Apparently the two factors of stress of mother rotation plus LCM act synergistically to the detriment of the nursing infant. An important question arises as to whether these results have any direct bearing on the human situation. Although an answer to this question goes beyond the scope of these results, there appears to be some correlation between the mouse model and certain human environmental situations in which a similar combination of low-grade maternal infectious illness could combine with other nonspecific stressful psychological factors with a similar overall effect of greatly increased infant morbidity or mortality. Presumably this would be more likely in primitive or low socioeconomic populations. In animal experiments with neonatal infections it is evident that the importance of the mother-offspring interaction can be critical. The fact that psychological and other types of induced stress can influence the outcome of virus infections was demonstrated in 1957 by RASMUSSEN $e t$ al. [12] and subsequently confirmed by other workers $[3,4]$. In this laboratory, work with LCM virus [14] revealed similar results. Infectious agents may conceivably affect behavioral research in the above manner by accidental incorporation in experiments, particularly, if crowded populations were under study [11].

The experimental approach used in this study represents an attempt to investigate the interaction between behavioral mechanisms and infectious disease. Although the existence of such interaction is intuitively evident, it has so far been very elusive as a research subject. It is hoped that these results may stimulate further work in this area.

Summary

It has been shown that the mortality of infant mice suffering from lymphocytic choriomeningitis virus infection is influenced by maternal contact infection with the virus. Mother mice do not appear to suffer from the infection, but in infant mice, mortality was raised significantly. Mortality in offspring is further aggravated by subjecting the contact-infected mothers to mild 
stress (produced by exchanging litters) which does not affect normal mothers. The mechanism of the effect is not clear, and may involve humoral factors transmitted via the milk.

\section{References and Notes}

1. Benson, L. and Hotchin, J.: Antibody formation in persistent tolerant infection with lymphocytic choriomeningitis virus. Nature, Lond. 222: 1045 (1969).

2. Collins, D.N.; Weigand, H. and Hotahin, J.: The effects of pretreatment with X-rays on the pathogenesis of lymphocytic choriomeningitis in mice. II. The pathological histology. J. Immunol. 87: 682 (1961).

3. Friedman, S.B.; Ader, R. and Glasgow, L.A.: Effects of psychological stress in adult mice inoculated with Coxsackie B virus. Psychosom. Med. 27: 361 (1965).

4. Friedman, S.B. and Glasgow, L.A.: Psychological factors and resistance to infectious disease. Pediat. Clin. N. Amer. 13: 315 (1966).

5. Hotchin, J.: The role of immunological tolerance in neonatal infection of mice with lymphocytic choriomeningitis virus. Quart. Rev.Pediat. 16: 97 (1961).

6. Horchin, J.: The biology of lymphocytic choriomeningitis infection: Virus-induced immune disease. Cold Spr. Harb. Symp. quant. Biol. 27: 479 (1962).

7. Hotahin, J. and Benson, L.: The pathogenesis of lymphocytic choriomeningitis in mice: The effects of different inoculation routes and the footpad response. J. Immunol. 91: 460 (1963).

8. Hotchin, J.; Benson, L. and Srrora, E.: The detection of neutralizing antibody to lymphocytic choriomeningitis virus in mice. J. Immunol. 102: 1128 (1969).

9. Hotchin, J.; Benson, L. and Seamer, J.: Factors affecting the induction of persistent tolerant infection of newborn mice with lymphocytic choriomeningitis. Virology 18: 71 (1962).

10. Hotchin, J. and Weigand, H.: Studies of lympho- cytic choriomeningitis in mice. I. The relationship between age at inoculation and outcome of infection. J. Immunol. 86: 392 (1961).

11. KeELEY, K.: Prenatal influence on behavior of offspring of crowded mice. Science 135: 44 (1962).

12. Rasmussen, A.F., Jr.; Marsh, J.T. and Brill, N.Q.: Increased susceptibility to herpes simplex in mice subjected to avoidance-learning stress or restraint. Proc. Soc. exp. Biol., N.Y. 96: 183 (1957).

13. Scotr, J.P.: Critical periods in behavioral development. Science 138: 949 (1962).

14. Sikora, E.; Benson, L. and Hotchin, J.: The effect of stress on susceptibility to lymphocytic choriomeningitis virus disease. J.Infect. Dis. (to be published).

15. VolKerT, M.: Studies on immunological tolerance to lymphocytic choriomeningitis virus. A preliminary report on adoptive immunization of virus carrier mice. Acta path.microbiol.scand. 56: 305 (1962).

16. Weigand, H. and Hotchin, J. : Studies of lymphocytic choriomeningitis in mice. II. A comparison of the immune status of newborn and adult mice surviving inoculation. J. Immunol. 86: 401 (1961).

17. IM designates, in this article, the mortality of infant mice in the first 28 days of life, excluding those who die in the first 5 days.

18. Ohaus balance, Ohaus Scale Corporation, Union, NJ.

19. Initially 20 litters/group were inoculated. The results of the experiments were taken from day 5 , however, and whole litters dying prior to that time were considered to be poor mother-care fatalities and were omitted from the results, as were individual mice dying before day 5 .

20. The authors acknowledge the technical assistance of Miss Evelyn Keller, and the help of Mr. PerILIP Quickenton of the Department of Biostatistics who made the statistical analysis of our results.

21. Supported by National Institutes of Health Grant no. 5-R01-A1-03846-06.

22. Requests for reprints should be addressed to JoHN Horchun, M.D., Division of Laboratories and Research, New York State Department of Health, New Scotland Ave., Albany, NY 12201 (USA).

23. Accepted for publication August 29, 1969. 